\title{
Accounting Issues: An Essay Series Part VII-Liabilities
}

\author{
Judy Laux, Colorado College, USA
}

\begin{abstract}
This article, the seventh in the series, presents accounting for liabilities along with some related conceptual and measurement issues. Additional coverage is devoted to potential ethical dilemmas and both theoretical and empirical literature related to this set of accounting elements.
\end{abstract}

Keywords: liabilities, hierarchy, theory

\section{INTRODUCTION}

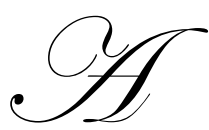

s Laux 2007(a) indicates, this series represents an attempt to restore to the introductory accounting course the theoretical structure now missing from most principles texts. Thus far the series has addressed the major assets, and now we turn briefly to the liabilities category. As those of you who are familiar with the series are aware, each article uses the hierarchy of accounting characteristics (displayed on the following page) along with a mountain-hiking analogy to describe some of the daily accounting dilemmas encountered at the base of the mountain, potential measurement and classification issues associated with the adjusting process in the foothills of the journey, and the goal to be reached at the mountain top-reflecting economic reality, thereby making the information useful for decision makers. For a refresher on the hierarchy, see the first article in the series, the only required preparation for tackling each of the other articles. The current article briefly reviews the fundamental accounting rules for the variety of liabilities, followed by a section outlining the conceptual framework connections and measurement issues. A favorite among student readers, the last section introduces some real-world examples of companies that have struggled with liability-related reporting. The section also looks at some of the conceptual and empirical literature devoted to liabilities.

\section{ACCOUNTING FOR LIABILITIES}

The accounting profession formally defines liabilities as probable future sacrifices arising from present obligations that result from past transactions or events [SFAC No. 6, 1985, paragraph 38; however, for a detailed conceptual discussion of the definition and recognition of liabilities, immerse yourself in Botosan et al., 2005!]. As you will recall from your introduction to accounting for liabilities, this category includes several important current liabilities (accounts payable, salaries and wages payable, and warranty obligations, for example) as well as longterm liabilities, such as bonds payable, mortgages, and liabilities under leases. The valuation of liabilities varies, with accounts payable typically valued at the gross amount to be paid to the supplier, and salaries and wages payable similarly valued. Obligations associated with warranties, however, require estimation on the part of the accountant who must weigh historical evidence in determining the value to report. Bonds payable are reported at "amortized cost," meaning that, if the company originally issued the bonds for more (or less) than face value ( $\$ 1000$ per bond) but will have to repay exactly $\$ 1000$ per bond at maturity, the bonds will initially be reported at the amount received but will be reported at maturity at the amount to be repaid. Thus, a premium (or discount) at issuance must be "amortized" (written off in some systematic way) over the life of the issue, and the carrying value of the bond issue changes along the way.

In introducing students to mortgages payable, introductory accounting texts use this as yet another opportunity to discuss the time value of money (the concept of present value) to determine the monthly (or annual) payment necessary to reduce the original cost to zero over the life of the loan, given a specified rate of interest. You 
probably constructed a partial amortization schedule so that you could see that mortgages payable are shown on the balance sheet at the amount of the unpaid principal as of the balance sheet date. Finally, as you no doubt discovered in your principles course, lease obligations constitute one of the most controversial long-term liabilities. The term "off balance sheet financing" typically appears in most discussions of leases, describing the scenario wherein a company, eager to keep debt off its balance sheet, constructs agreements in such a way as to avoid the recognition of both an asset ("Equipment Under Long-term Lease," for example) and a long-term liability, preventing deterioration of such measures as the debt ratio. The following section discusses the conceptual ramifications of this type of accounting game.

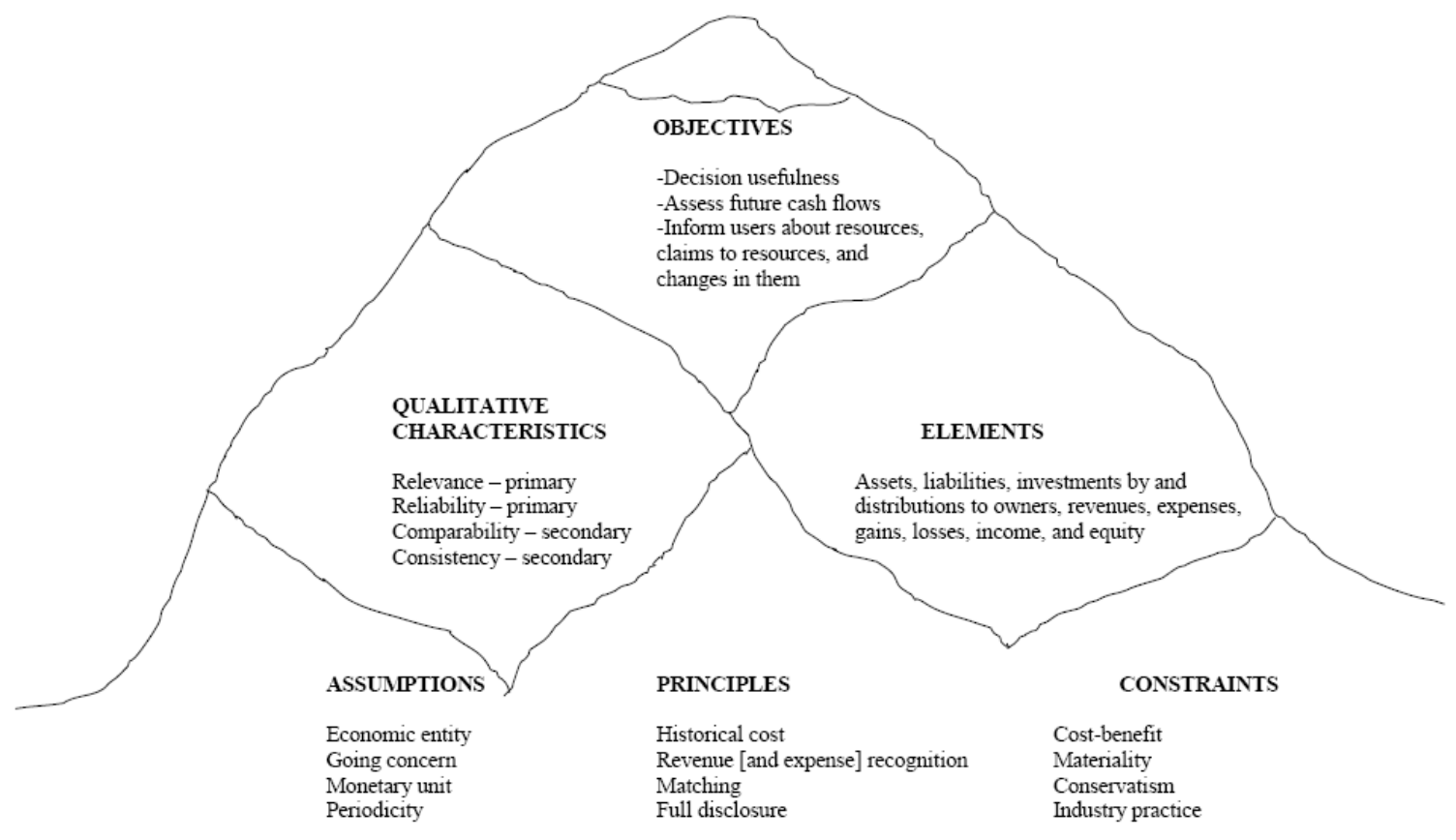

\section{CONNECTIONS TO THE CONCEPTUAL FRAMEWORK}

As this series emphasizes, the overriding concern is that accounting information be useful to investors and creditors in assessing both the potential future cash flows of the business and the financial status of the firm, with relevance and reliability constituting the primary qualities that render this utility. We can judge the accounting for liabilities on these dimensions. The distinction between current and long-term liabilities, for example, helps investors and creditors determine the timing of the impact on cash flows from the firm. If an account payable is due in 30 days, we can assume cash will flow out of the firm in that time span. If bonds payable are not due for ten years, we can assume that, with the exception of the required semi-annual interest payments (some of which might appear as the current liability interest payable), the cash flow impact will probably not take place for some time (unless management decides the financial markets are such that calling the bonds early would benefit the firm and its stockholders). Thus most investors and creditors find the classification of liabilities relevant to the assessment of both cash flow and financial status. From a decision maker's perspective, liquidity assessment is at the core of a number of ratios, including the current ratio (current assets divided by current liabilities) and the quick (or acid test) ratio (current assets excluding inventory and prepaid assets divided by current liabilities). [For a real-world example 
of the importance of debt management, see Vames, 2002.] Leverage, a longer-term look at the financial structure and risk of a firm, is measured by the debt ratio (total liabilities divided by total assets). [Spiceland et al., 2007, offers good coverage of ratio analysis on pp. 636-37 and 680-82.] Investors and creditors alike find these measures a necessary part of their toolkit for judging the financial well being of a firm; thus the information is deemed relevant.

The reliability of both accounts payable and salaries payable is generally high, but for warranties, which depend on the accountant's judgment, reliability is less certain. The estimation of probable future sacrifices from honoring warranties is necessary, however, to adhere to the matching principle so that the expense associated with the current year's sales appears on the current income statement even though the cash outflows associated with honoring the warranty obligation might not occur until a later period. Disclosure of the estimation technique is required, and consistency in approach is expected. Conservatism would dictate that, given a defensible range for the estimated warranty liability to appear on the balance sheet, the accountant should err on the high side, resulting in a higher warranty expense (expense recognition) on the income statement. Of course, as with any scenario requiring judgment, accountants can receive pressure to use these estimates to smooth income, and this ethical dilemma must be confronted - with sound judgment prevailing, if economic reality is truly the end pursued.

The valuation of another liability, bonds payable, offers a few interesting conceptual ramifications, as well. While the bonds are valued at face value less any unamortized discount or plus any unamortized premium, the true "market" value might be considerably higher or lower. Bondholders buy and sell bonds in the marketplace every day, and the prices of those bonds vary as interest rates rise and fall. Bonds reported on the balance sheet date at $\$ 110,000$ ( $\$ 100,000$ face value plus $\$ 10,000$ of unamortized premium), for example, might be selling for only $\$ 100,000$ in the open market because interest rates have risen since issuance. If the company elects to buy these bonds back, it could retire the liability for $\$ 100,000$ in cash. Theoretically then, the liability is overstated on the balance sheet. Only if the company actually buys the bonds back would the liability be retired and a $\$ 10,000$ gain recognized on the income statement. Matching is at issue here (as the gain is recorded in the period realized and matched with the expenses of that period). Finally, the choice of the effective interest method of amortizing premiums and discounts recognizes a more relevant figure for true interest expense during a period; the straight-line method can only be used when the difference is insignificant in amount, an application of the materiality constraint.

Another troublesome liability and one that receives much press is the obligation associated with leases. This is the "off balance sheet financing" game referred to earlier. When companies structure leases of long-term assets in such a way that neither a long-term asset nor a liability is reported, they are choosing to stray from the path that leads to the mountain top. In accounting jargon this is referred to as a betrayal of the "economic substance over legal form" mantra, which states that an accountant's primary objective is to reflect the economic reality of an event rather than allowing the legal description to dictate reported values. If an aircraft is being used for most of its useful life and a company has promised to make cash payments throughout that life, even though legal title does not formally pass from the lessor to the company, the firm in economic reality "owns" the aircraft and has assumed a liability to pay for its use. Thus both an asset and a liability should be recorded and reported. You might ask, why would a company choose to keep an asset and a liability off its balance sheet? Isn't it just a "wash," since one is a "good" thing (an asset) and the other a "bad" thing (a liability)? The fact is, for ratios such as the debt to asset ratio (always less than one), adding an equal amount to both the numerator and denominator drives the ratio up. Consider a firm with $\$ 2$ million in liabilities and $\$ 4$ million in assets (with a ratio of .50). If the firm is considering leasing $\$ 1$ million in new assets, the new ratio would be $\$ 3$ million to $\$ 5$ million or .60. This increased leverage could be viewed negatively by investors and creditors. More discussion about the ethical aspects of this reality appears in the following section, which looks at some real-world reporting problems and other literature devoted to accounting for liabilities.

\section{LIABILITY ACCOUNTING IN THE NEWS AND LITERATURE}

Recently, headlines have proliferated concerning the debt-market slowdown related to the sub-prime mortgage market. A Wall Street Journal article ["Risks Sparking Bailout Were Still in Shadows By Post-Enron Rules"] asks how banks were able to keep the risk off their balance sheets. "Structured investment vehicles" (SIVs) 
have become the new "special purpose entities" (SPEs) of the old Enron days. In short, banks have managed to skirt the "post-Enron rule changes meant to curtail off-balance-sheet activity... [by] ... structuring the vehicles so that the risk of loss associated with them was ostensibly transferred to other parties" (p. C1). While these SIVs would have appeared as assets on the books of banks, the point is that the liability to shoulder the risk of default was nowhere to be seen. Banks have also made the headlines because of another quirky liability accounting rule that allows banks to generate profits from decreases in the value of their own debt. [For an example, see "The Gold at Crunch's End," p. C1.] If we apply this accounting rule to regular (non-financial) corporations, companies whose credit quality is deteriorating could actually report gains on their income statements from such deterioration [See Lipe, 2002.], a situation that fails to align with our goals of reflecting economic reality and advancing decision usefulness. Chasteen and Ransom [2007] make a compelling case that liabilities should be reported at the present value of future cash flows discounted at the risk-free rate of interest, removing a company's credit standing from liability valuation.

No "scandals"-related section can go without mention of Enron and its off-balance-sheet antics, and a good article to look at is Chandra et al. [2006], which investigates the widespread use of external entities to shield debt from financial statement readers' eyes.

In one area-measuring and reporting the liability associated with frequent flyer programs-reflecting economic reality and enhancing usefulness of accounting information actually have come a long way:

When airlines first started offering frequent-flyer bonuses, everyone assumed that they could accommodate the freeticket holders with otherwise-empty seats. That made the additional cost of the program so minimal that airlines didn't accrue it or report the small liability. But, as more and more paying passengers have been crowded off flights by frequent-flyer awardees, the loss of revenues has grown enormously. For example, United Airlines recently reported a liability of $\$ 1.4$ billion for advance ticket sales, some of which pertains to free frequent-flyer tickets. [Kieso et al., p. 536]

As Spiceland et al. note (p. 656), Northwest Airlines recorded a liability for these awards of $\$ 215$ million on their December 31, 2004 balance sheet.

One area of concern arises in today's litigious, environmentally conscientious world: liabilities associated with pollution and toxic waste cleanup, often referred to as environmental liabilities. Kieso et al. estimates the average environmental cost per firm in various industries:

high-tech firms, $\$ 2$ million (6.1\% of revenues); utilities, $\$ 340$ million (6.1\% of revenues); steel and metals, $\$ 50$ million (2.9\% of revenues), and oil companies, \$430 million (1.9\% of revenues). [p. 536]

They offer a standard of comparison to determine the magnitude of these figures - the average pretax profit of the 500 largest U.S. manufacturing firms was 7.7 percent of sales. One good empirical article [Clarkson et al., 2004, p. 329] estimates average unrecorded liabilities of $\$ 560$ million for the high-polluting firms in the pulp and paper industry, an astounding 16.6 percent of market capitalization! Because these liabilities are recorded only when they can be estimated AND the probability of honoring them is high, companies can shirk their economic duty to report the liabilities formally.

Accounting for pension-related obligations has also seen much coverage in the press. Not only is the accounting quite complex, but it also relies on a number of estimates and assumptions, another occasion for potential accounting mischief. Perhaps a bigger issue is that many companies have plans that are grossly under-funded. Stock market booms have sometimes caused pension funds to be over-funded, and managers diverted funds to other uses, inciting the ire of the intended recipients and the general public. Of course, depressed markets exacerbate this under-funding.

A host of conceptual literature exists relating to liability accounting. The AAA Financial Accounting Standards Committee [2000, p. 506] offers a good summary of the issues surrounding fair-value accounting for financial instruments, including liabilities, noting that while neutrality (a subset of reliability) is important, the real 
economic value of fair value reporting lies in its relevance to users. Barth [2006, pp. 274-75] explains the International Accounting Standards Board's justification for fair value accounting in the context of the accounting framework. For an excellent explanation of reasons to lease and how that reasoning aligns with the hierarchy of accounting characteristics and accounting standards, see Mohnson [2001, pp. 279ff.] Finally, Chasteen and Ransom [2007, pp. 120-22] present a good history of liability accounting. Suffice it to say that accountants are struggling to better approximate economists' definition of income in a shift away from reliability towards relevance, and accounting changes in your lifetime may well be enormous. So don't just sit there-help chart the course!

\section{THIS SERIES CONTINUES}

The current installment described the accounting for debts of corporations and connected the theoretical constructs of the conceptual framework with this accounting category. It featured a few headline stories and reviewed some of the related literature. The next installment in the series will investigate stockholders' equity and its conceptual challenges.

\section{AUTHOR INFORMATION}

Judith Laux is a Professor of Economics and Business at Colorado College, teaching and researching in the areas of accounting and finance.

\section{REFERENCES}

1. American Accounting Association's Financial Accounting Standards Committee. 2000. "Response to the FASB Preliminary Views: Reporting Financial Instruments and Certain Related Assets and Liabilities at Fair Value." Accounting Horizons. Vol. 14, No. 4: 501-508.

2. $\quad$ Barth, Mary E. 2006. "Including Estimates of the Future in Today's Financial Statements." Accounting Horizons. Vol. 20, No. 3: 271-285.

3. Botosan, Christine, Lisa Koonce, Stephen G. Ryan, Mary S. Stone, and James M. Whalen. 2005.

"Accounting for Liabilities: Conceptual Issues, Standard Setting, and Evidence from Academic Research." Accounting Horizons. Vol. 19, No. 3: 159-186.

4. Chandtra, Uday, Michael L. Ettredge, and Mary S. Stone. 2006. "Enron-Era Disclosure of Off-BalanceSheet Entities." Accounting Horizons. Vol. 20, No. 3: 231-252.

5. Chasteen, Lanny G. and Charles R. Ransom. 2007. "Including Credit Standing in Measuring the Fair Value of Liabilities-Let's Pass This One to the Shareholders." Accounting Horizons. Vol. 21, No. 2: 119-135.

6. Clarkson, Peter M., Yue Li, and Gordon D. Richardson. 2004. "The Market Valuation of Environmental Capital Expenditures by Pulp and Paper Companies." The Accounting Review. Vol. 79, No. 2: 329-353.

7. Financial Accounting Standards Board. 1985. "Elements of Financial Statements." Statement of Financial Accounting Standards, No. 6. Stamford, Conn.

8. Kieso, Donald E., Jerry J. Weygandt, and Terry D. Warfield. 2003. Fundamentals of Intermediate Accounting. United States: John Wiley \& Sons, Inc.

9. Laux, Judith A. 2007. "Accounting Issues: An Essay Series Part I-Introduction to Accounting Theory and 'Cash.'" Journal of College Teaching \& Learning. Vol. 4, No. 1: 61-65.

10. 2007. "Accounting Issues: An Essay Series Part II-Accounts Receivable." Journal of College Teaching \& Learning. Vol. 4, No. 4: 1-6.

11. 2007. "Accounting Issues: An Essay Series Part III—Inventory.” Journal of College

Teaching \& Learning. Vol. 4, No. 8: 1-6.

12. 2007. "Accounting Issues: An Essay Series Part IV—Property, Plant, \& Equipment." Journal of College Teaching \& Learning. Vol. 4, No. 11, 41-46.

13. 2008. "Accounting Issues: An Essay Series Part V_Intangible Assets." Journal of College Teaching \& Learning. Vol. 5, No. 1: 61-67.

14. _ 2008. "Accounting Issues: An Essay Series Part VI—Investments in Securities." Journal of College Teaching \& Learning. Vol. 5, No. 6: 37-41. 
15. Lipe, Robert C. 2002. "Fair Valuing Debt Turns Deteriorating Credit Quality into Positive Signals for Boston Chicken." Accounting Horizons. Vol. 16, No. 2: 169-181.

16. Mohnson, Dennis W. 2001. "The Conceptual Framework and Accounting for Leases." Accounting Horizons. Vol. 15, No. 3: 275-287.

17. $\quad$ Reilly, David. 2007. "The Gold at Crunch's End." Wall Street Journal. 9-28-07: Cl.

18. _ 2007. "Risks Sparking Bailout Were Still in Shadows By Post-Enron Rules." Wall Street Journal. 10-16-07: C1.

19. Spiceland, J. David, James F. Sepe, and Lawrence A. Tomassini. 2007. Intermediate Accounting, (h $^{\text {th }}$ ed. McGraw-Hill.

20. Vames, Steven. 2002. "Credit Quality, Stock Investing Seem to Go Hand in Hand." Wall Street Journal. April 1, 2002: R4.

\section{NOTES}

